\title{
The Influence of Temperature and Growth Rate on the Quantitative Relationship Between Potassium, Magnesium, Phosphorus and Ribonucleic Acid of Aerobacter aerogenes Growing in a Chemostat
}

\author{
By J. W. DICKS AND D. W. TEMPEST \\ Microbiological Research Establishment, Porton Down, Wiltshire
}

(Received 27 June 1966)

\begin{abstract}
SUMMARY
The variations in potassium, magnesium and phosphorus contents of Aerobacter aerogenes grown in a chemostat, were measured as functions of the RNA content of the organisms. The RNA content was varied by altering temperature at a fixed dilution rate under potassium-limiting conditions, and by varying the growth rate at a fixed temperature under conditions of both magnesium- and phosphate-limitation. Changes in RNA were accompanied by corresponding changes in these other cellular components such that a molar stoichiometry close to $1: 4: 5: 8$ for magnesium, potassium, RNA (nucleotide) and phosphorus, respectively, was maintained. The only significant deviation from this ratio was observed in phosphatelimited organisms at low growth rates; these organisms possessed considerable amounts of carbohydrate. It is suggested that potassium, magnesium and phosphate are implicated in polysaccharide synthesis, thus changing the quantitative relationship between these three components and RNA previously observed. The results support the suggestion that most of the potassium in growing $A$. aerogenes is required to maintain the functional state of ribosomal particles.
\end{abstract}

\section{INTRODUCTION}

A wide range of growing cells require potassium and accumulate it to high intracellular concentrations (Steinbach, 1962; Lester, 1958; Rouf, 1964). The importance of potassium in certain enzyme-catalysed reactions (Dixon \& Webb, 1964), particularly those which involve phosphate transfer (Lardy, 1951) may explain its frequently reported participation in carbohydrate metabolism (Pulver \& Verzar, 1940; Roberts, Roberts \& Cowie, 1949; Eddy \& Hinshelwood, 1951; Duguid \& Wilkinson, 1954) and respiration (Krebs, Whittam \& Hems, 1957 ; Perry \& Evans, 1961; Blond $\&$ Whittam, 1965). It seemed justifiable, however, to inquire whether these catalytic roles demand the presence of potassium in growing cells in concentrations which make it the major metal nutrient. We suggested an alternative explanation (Dicks \& Tempest, 1966; Tempest, Dicks \& Hunter, 1966), derived from an investigation of the growth of Aerobacter aerogenes in a chemostat under conditions of potassium-limitation. A growth rate-independent molar stoichiometry between the magnesium, potassium, RNA (nucleotide) and phosphorus contents of the organism of approximately $1: 4: 5: 8$ was interpreted in terms of potassium participation in the maintenance of a functional configuration of ribosomal structures. At present, 
this hypothesis is based on evidence derived from the investigation of a single species of bacterium grown under one type of growth limitation. If the suggestion is tenable, then it might be anticipated that the described stoichiometry exists in many growing cells, regardless of the growth conditions. 'The aim of the work described in the present paper was to extend our observations on the same organism growing at different temperatures and under different growth limitations.

\section{METHODS}

Organism. Aerobacter aerogenes, NCTC 418, maintained by monthly subculture on tryptic meat digest agar slopes, was used throughout.

Growth conditions. Cultures were grown in $0.5 \mathrm{l}$. chemostats of the type described by Herbert, Phipps \& Tempest (1965), in which the $\mathrm{pH}$ value $(6 \cdot 5 \pm 0 \cdot 1)$ and temperature $\left(35^{\circ}\right.$, except when stated otherwise) were each controlled automatically. Foaming of the cultures was diminished by the regular addition of $\mathbf{0} \cdot \mathbf{1}-\mathbf{0} \cdot \mathbf{2} \mathrm{ml}$. Polyglycol P-2000 antifoam (Dow Chemical Co., Midland, Michigan, U.S.A.).

The $\mathrm{K}^{+}$-limited culture medium was identical to that previously described by Tempest et al. (1966). The $\mathrm{Mg}^{2+}$-limited culture medium contained: $\left(\mathrm{NH}_{4}\right) \mathbf{H}_{2} \mathbf{P O}_{4}$, $4.5 \times 10^{-2} \mathrm{M} ;\left(\mathrm{NH}_{4}\right)_{2} \mathrm{SO}_{4}, 2.5 \times 10^{-2} \mathrm{M} ; \mathrm{Na}_{2} \mathrm{HPO}_{4}, 5.0 \times 10^{-3} \mathrm{M} ; \mathrm{K}_{2} \mathrm{SO}_{4}, 1.0 \times 10^{-3} \mathrm{M}$ or $2.0 \times 10^{-3} \mathrm{M}$; citric acid, $1.0 \times 10^{-3} \mathrm{M}: \mathrm{MgCl}_{2}, 2.5 \times 10^{-4} \mathrm{M} ; \mathrm{CaCl}_{2}$ and $\mathrm{FeCl}_{3}$, each $1.0 \times 10^{-4} \mathrm{M} ; \mathrm{MnCl}_{2}, 2.5 \times 10^{-5} \mathrm{M} ; \mathrm{CuCl}_{2}$ and $\mathrm{Na}_{2} \mathrm{MoO}_{4}$, each 5.0 $\times 10^{-6} \mathrm{M}$; glycerol, $30 \mathrm{mg} . / \mathrm{ml}$. The $\mathrm{PO}_{4}{ }^{3-}$-limited culture medium contained $\left(\mathrm{NH}_{4}\right)_{2} \mathrm{SO}_{4}, 5.0 \times 10^{-2} \mathrm{M}$; $\mathrm{Na}_{2} \mathrm{HPO}_{4}, 2.0 \times 10^{-3} \mathrm{M} ; \mathrm{K}_{2} \mathrm{SO}_{4}, 1.5 \times 10^{-3} \mathrm{M}$ or $2.5 \times 10^{-3} \mathrm{M}$; citric acid, $1.0 \times 10^{-3} \mathrm{M}$; $\mathrm{MgCl}_{2}, 1 \cdot 25 \times 10^{-3} \mathrm{M}$; the $\mathrm{Ca}^{2+}, \mathrm{Fe}^{3+}, \mathrm{Mn}^{2+}, \mathrm{Cu}^{2+}$ and molybdate concentrations, and the glycerol content, were identical to those described for the $\mathrm{Mg}^{2+-}$ limited medium.

All media were prepared in $20 \mathrm{l}$. volumes by using distilled water which had passed through a mixed-bed ion-exchange resin. The $\mathrm{pH}$ values of $\mathrm{Mg}^{2+-}$ and $\mathrm{K}^{+-}$ limited media were within the range $\mathrm{pH} 5 \cdot 20-5 \cdot 30$, and of $\mathrm{PO}_{4}{ }^{3-}$-limited media within the range $\mathrm{pH} 3 \cdot 20-3 \cdot 30$ after autoclaving $\left(121^{\circ}, 30 \mathrm{~min}.\right)$. Adjustment to $\mathrm{pH} 6.5$ was attained in the culture vessel by the operation of the automatic $\mathrm{pH}$ control unit.

Samples, not exceeding $\mathbf{2 5} \mathrm{ml}$. (5\% of the culture volume), were taken directly from the culture vessel for analysis.

Analytical procedures. Bacterial concentration (equiv. mg. dry weight organisms/ ml. culture), total cellular RNA and carbohydrate were estimated according to methods previously described by Tempest, Hunter \& Sykes (1965). Total phosphorus was determined by the method of King (1951) after the bacteria has been digested with $60 \%(\mathrm{w} / \mathrm{v})$ perchloric acid. Intracellular magnesium was determined by a modification (Tempest \& Strange, 1966) of the Titan Yellow method of Gardner (1946).

Identification of glycogen. The methods of Strange, Dark \& Ness (1961) were employed for the extraction and identification of glycogen from $\mathrm{PO}_{4}{ }^{3-}$-limited organisms grown at a dilution rate of $0.09 \mathrm{hr}^{-1}$. Briefly, the procedure involved water-extraction of disrupted organisms, treatment of the extract with cold trichloracetic acid (TCA) to a final concentration of $2.5 \%(\mathrm{w} / \mathrm{v})$ to remove protein and nucleic acids, and then precipitation of glycogen from the neutralized dialysed solution with ethanol. After washing in ethanol and drying, the isolated material 
gave a red colour with iodine and readily dissolved in water to an opalescent solution. It contained $66 \%$ carbohydrate which, after acid hydrolysis and chromatographic analysis (using the spray reagents of Trevelyan, Proctor \& Harrison (1950), and Partridge (1949)) was shown to consist entirely of glucose.

Potassium determinations were performed according to the method described by Tempest et al. (1966), in which the bacterial potassium content is derived by subtracting the residual potassium in the culture supernatant from the total potassium in the culture, after estimation by flame photometry. This method is facilitated by the virtually complete uptake of potassium under $\mathbf{K}^{+}$-limiting conditions. However, when another component of the medium limits growth, potassium must be supplied in excess of requirement. Since the accuracy of this particular determination is dependent upon subtracting a small value from a relatively large one, the potassium content of $\mathrm{Mg}^{2+}$ - and $\mathrm{PO}_{4}{ }^{3-}$-limited culture media has been maintained at a value which ensures its presence in excess at all rates of growth without significantly decreasing the sensitivity of the analytical procedure.

Viability measurements were made by the slide culture technique of Postgate, Crumpton \& Hunter (1961). Under all conditions of growth reported in this paper, the degree of viability exceeded $90 \%$.

\section{RESULTS}

Effect of temperature on the steady state composition of $K^{+}$-limited organisms growing at a fixed dilution rate

If the growth rate-dependent variations in magnesium, potassium and phosphorus contents of Aerobacter aerogenes are connected primarily with the changes in RNA content of the organisms (Dicks \& Tempest, 1966; Tempest et al. 1966), then the changes in RNA content which accompany different incubation temperatures at a fixed growth rate (Tempest \& Hunter, 1965) should also be accompanied by changes in the potassium, magnesium and phosphorus contents of the organisms.

The influence of changes in the incubation temperature on $\mathbf{K}^{+}$-limited cultures of Aerobacter aerogenes, growing at a dilution rate of $\mathbf{0 . 2} \mathbf{h r}^{-1}$, is shown in Table 1. Decrease in temperature from $35^{\circ}$ to $25^{\circ}$ caused a $36 \%$ increase in bacterial $\mathrm{RNA}$ content; increases in bacterial potassium, phosphorus and magnesium were $33 \%$,

Table 1. Analysis of $K^{+-l i m i t e d ~ A e r o b a c t e r ~ a e r o g e n e s ~ N C T C ~} 418$ grown at different temperatures

\begin{tabular}{|c|c|c|c|c|c|}
\hline Temp. $\left(^{\circ}\right)$ & $\begin{array}{c}\text { Yield } \\
\text { (g. dry bac- }\end{array}$ & $\mathbf{K}^{+}$ & $\begin{array}{c}\mathrm{Mg}^{2+} \\
\text { (g. } / 100\end{array}$ & $\begin{array}{c}\mathbf{P} \\
\text { bacteria) }\end{array}$ & RNA \\
\hline 35 & $97 \cdot 1$ & 1.03 & $0 \cdot 157$ & $1 \cdot 68$ & $11 \cdot 6$ \\
\hline 35 & $93 \cdot 5$ & $1 \cdot 07$ & $0 \cdot 160$ & $1 \cdot 84$ & $12 \cdot 6$ \\
\hline 30 & $84 \cdot 8$ & $1 \cdot 18$ & $0 \cdot 156$ & 1.90 & $13 \cdot 1$ \\
\hline 30 & $82 \cdot 7$ & $1 \cdot 21$ & $0 \cdot 173$ & $1 \cdot 95$ & $13 \cdot 5$ \\
\hline 25 & 70.5 & $1 \cdot 42$ & $0 \cdot 187$ & $2 \cdot 33$ & $16 \cdot 6$ \\
\hline 25 & $72 \cdot 5$ & $1 \cdot 38$ & $0 \cdot 189$ & $2 \cdot 28$ & $16 \cdot 3$ \\
\hline
\end{tabular}


$36 \%$ and $19 \%$, respectively. The high degree of correlation between the increases in RNA, potassium and phosphorus is shown by the constant $\mathrm{P} / \mathrm{K}^{+}, \mathrm{RNA} / \mathrm{P}$ and RNA/K+ molar ratios (Figs. 1, 2); the more limited degree of correlation between magnesium content and the other three components is reflected in somewhat temperaturedependent $\mathrm{K}^{+} / \mathrm{Mg}^{2+}, \mathrm{P} / \mathrm{Mg}^{2+}$ and $\mathrm{RNA} / \mathrm{Mg}^{2+}$ molar ratios, also shown in these figures.

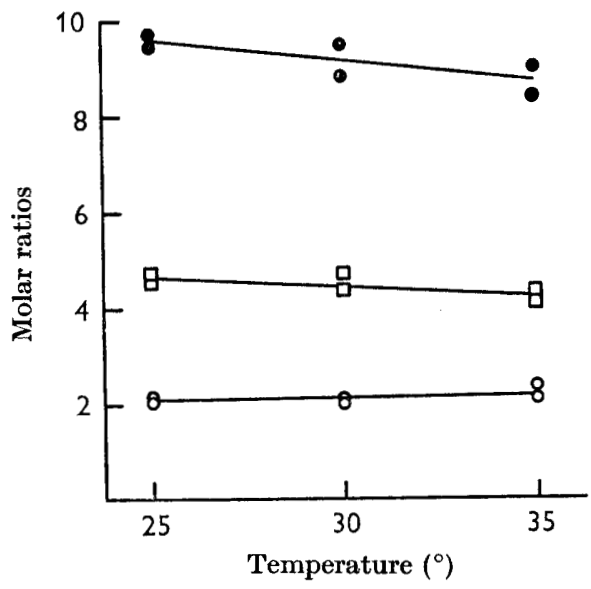

Fig. 1

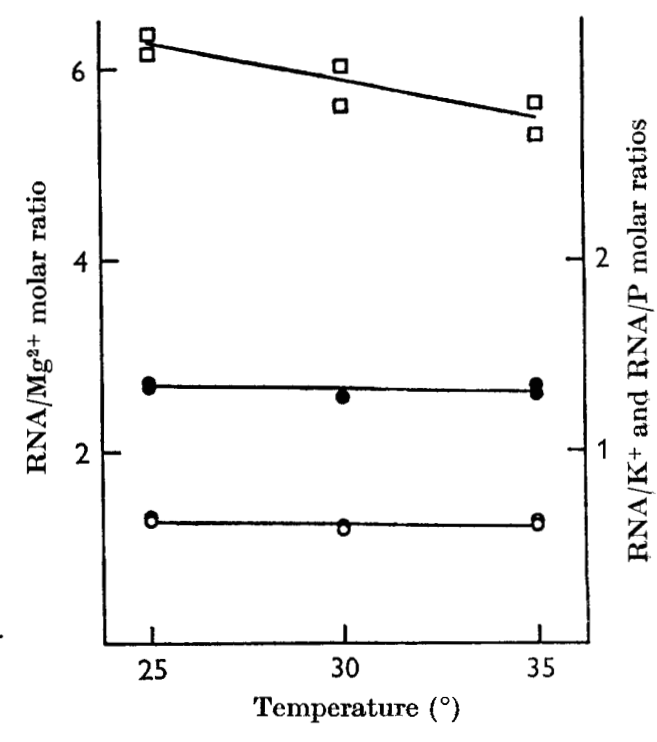

Fig. 2

Fig. 1. Stoichiometry between bacterial potassium, magnesium and phosphorus in $\mathrm{K}^{+}$-limited chemostat cultures of Aerobacter aerogenes NCTC 418, grown at different temperatures. Molar ratios: $\odot$, phosphorous: magnesium; $\square$, potassium:magnesium; $O$, phosphorus : potassium.

Fig. 2. Stoichiometry between bacterial RNA and potassium, magnesium and phosphorus in $\mathrm{K}^{+}$-limited chemostat cultures of Aerobacter aerogenes NCTC 418, grown at different temperatures. For the purpose of calculating molar ratios, an average molecular weight for RNA-nucleotide of 340 was assumed. Molar ratios : $\square$, RNA (nucleotide): magnesium; O, RNA (nucelotide):potassium; $O$, RNA (nucleotide): phosphorus.

\section{Effect of growth rate on the steady state composition of $\mathrm{Mg}^{2+}$-limited organisms growing at a fixed temperature}

The results presented in Table 2 were obtained from an experiment similar to that from which the initial observations on the stoichiometry between intracellular potassium, magnesium, phosphorus and RNA were made (Tempest et al. 1966), but in which magnesium was made the growth-limiting component of the medium, potassium being supplied in excess of requirement. At dilution rates of $0 \cdot 10$ and $0 \cdot 20 \mathrm{hr}^{-1}$, the $\mathrm{K}^{+}$concentration of the medium was set at $2 \mathrm{mM}\left(1 \mathrm{mM}-\mathrm{K}_{2} \mathrm{SO}_{4}\right)$, a proportion of which was not taken up by the organisms and could be measured in the culture supernantant fluid (see Methods). However, when the dilution rate was raised to $0.29 \mathrm{hr}^{-1}$, which imposed a growth rate well below the maximum usually observed for the organism growing in a simple salts medium, 'wash-out' occurred. This phenomenon was readily reversed by increasing the potassium concentration 
Table 2. Analysis of $\mathrm{Mg}^{2+}$-limited Aerobacter aerogenes NCTC 418 grown at different dilution rates

Values quoted in this table were obtained from samples collected during 'steady state' growth at each dilution rate (D)

\begin{tabular}{|c|c|c|c|c|c|}
\hline D & $\begin{array}{c}\text { Bacterial } \\
\text { concentration } \\
\text { (equiv. mg. dry wt. }\end{array}$ & $\mathbf{K}^{+}$ & $\begin{array}{c}\mathrm{Mg}^{2+} \\
\text { (g./100 g }\end{array}$ & $\underset{\text { acteria }}{\mathbf{P}}$ & RNA \\
\hline $0 \cdot 10$ & $5 \cdot 56$ & 0.89 & $0 \cdot 115$ & $1 \cdot 60$ & $9 \cdot 7$ \\
\hline $0 \cdot 20$ & 3.96 & $1 \cdot 14$ & $0 \cdot 136$ & 1.74 & $11 \cdot 1$ \\
\hline 0.29 & 3.04 & $1 \cdot 14$ & $0 \cdot 158$ & 1.89 & $12 \cdot 1$ \\
\hline $0 \cdot 48$ & $2 \cdot 67$ & 1.52 & $0 \cdot 192$ & $2 \cdot 28$ & $15 \cdot 4$ \\
\hline $0 \cdot 68$ & $2 \cdot 44$ & $1 \cdot 67$ & 0.201 & $\mathbf{2} \cdot 34$ & $16 \cdot 8$ \\
\hline
\end{tabular}

of the medium to $4 \mathrm{~mm}$, and 'steady-state' conditions were maintained on subsequent increases in dilution rate to $0 \cdot 48$ and $0 \cdot 68 \mathrm{hr}^{-1}$.

The $73 \%$ increase in RNA content of the organisms between growth rates of 0.10 and $0.68 \mathrm{hr}^{-1}$ closely matched the increase in cellular magnesium $(75 \%)$ and potassium $(88 \%)$. The values shown in Figs. 3 and 4 make clear that the stoichiometry between RNA, potassium and magnesium remained independent of growth rate as the cellular content of individual components increased. The phosphorus content of the organisms also changed considerably with growth rate, increasing $46 \%$ over the sevenfold increase in dilution rate. The degree to which the discrepancy between increase in cellular phosphorus and increase in potassium, magnesium and RNA contents affected the quantitative relationship between this

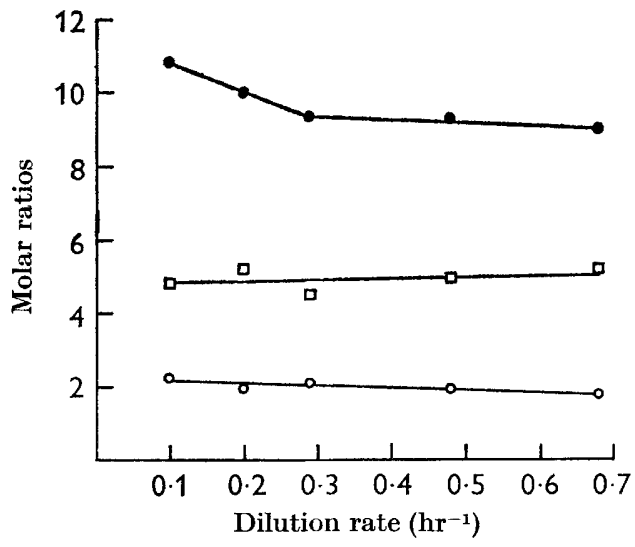

Fig. 3

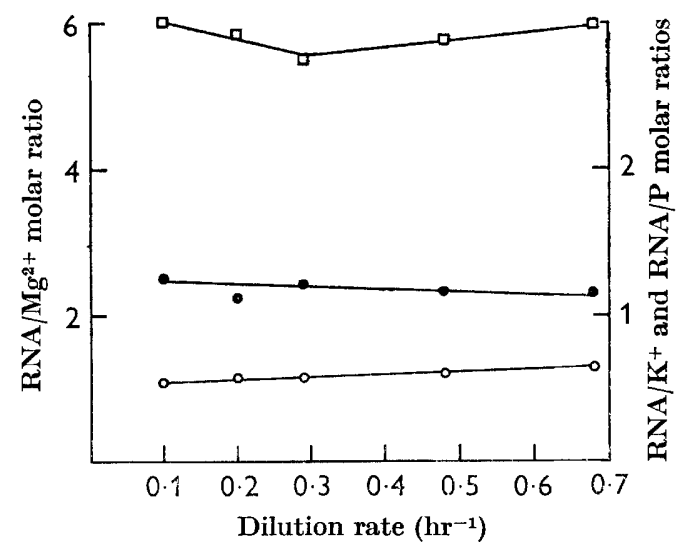

Fig. 4

Fig. 3. Stoichiometry between bacterial potassiun, magnesium and phosphorus in $\mathbf{M g}^{2+}$ limited chemostat cultures of Aerobacter aerogenes NCтc 418, grown at different dilution rates. Molar ratios: $\odot$, phosphorus:magnesium; $\square$, potassium:magnesium; $O$, phosphorus; potassium.

Fig. 4. Stoichiometry between bacterial RNA and potassium, magnesium and phosphorus in $\mathrm{Mg}^{2+}$-limited chemostat cultures of Aerobacter aerogenes NCTC 418, grown at different dilution rates. For the purpose of calculating molar ratios, an average molecular weight for RNA-nucleotide of $\mathbf{3 4 0}$ was assumed. Molar ratios: $\square$, RNA (nucleotide) : magnesium; , RNA (nucleotide): potassium; O, RNA (nucleotide): phosphorus. 
component and the other three is seen in variations in the $\mathbf{P} / \mathrm{K}^{+}, \mathbf{P} / \mathbf{M g}^{2+}$ and RNA/P ratios (Figs. 3, 4). It is interesting to compare the phosphorus content of Aerobacter aerogenes as a function of growth rate under $\mathbf{M g}^{2+}$-limiting conditions in the present experiment with corresponding values for $\mathbf{K}^{+}$-limited cultures (see Table 2 of Tempest et al. 1966). The value presented here for a dilution rate of $0 \cdot 68 \mathrm{hr}^{-1}(2 \cdot 34 \%$ of dry weight) corresponds very closely with values of $2 \cdot 44$ and $\mathbf{2 \cdot 3 9} \%$ at dilution rates of 0.69 and $0.70 \mathrm{hr}^{-1}$, respectively, for $\mathrm{K}^{+}$-limited organisms. At a dilution rate of $0 \cdot 10 \mathrm{hr}^{-1}$, however, the corresponding values are $\mathbf{1} \cdot 60 \%$ ( $\mathrm{Mg}^{2+-}$-limitation) and $1.31 \%\left(\mathrm{~K}^{+}\right.$-limitation). Thus, the partial breakdown in the stoichiometry between cellular phosphorus and the other components in $\mathbf{M g}^{2+}$ limited organisms seems to be the result of a relatively high phosphorus content of these organisms at low dilution rates.

\section{Effect of growth rate on the steady-state composition of $\mathrm{PO}_{4}{ }^{3-l i m i t e d}$ organisms growing at a fixed temperature}

It is evident from Table 3 that the increases in cellular potassium, magnesium phosphorus and $\mathrm{RNA}$ for $\mathbf{P O}_{4}{ }^{3-}$-limited organisms over an eightfold increase in growth rate were greater than the corresponding increases in $\mathbf{M g}^{2+-}$ limited (Table $\mathbf{2}$ ) and $\mathrm{K}^{+}$-limited organisms (Tempest et al. 1966). Between dilution rates of 0.09 and $0.71 \mathrm{hr}^{-1}$, cellular RNA increased by over $270 \%$, cellular magnesium by $200 \%$ cellular phosphorus by $190 \%$ and cellular potassium by nearly $150 \%$. Under $\mathrm{K}^{+}$-limitation (Tempest et al. 1966, their Table 1) and $\mathrm{Mg}^{2+}$-limitation (Tempest et al. 1965, their Table 2), the carbohydrate content of the organisms was low, increasing in each case from about $2 \%$ of the dry weight at a dilution rate of 0.1 $\mathrm{hr}^{-1}$ to $4.5 \%$ at $0.8 \mathrm{hr}^{-1}$; $\mathrm{PO}_{4}{ }^{3-}$-limited organisms were different in that they contained $17-18 \%$ carbohydrate when grown at a dilution rate of $0.09 \mathrm{hr}^{-1}$ (Table 3). Fractionation of these organisms showed that the bulk of this carbohydrate was glycogen. The carbohydrate content diminished as growth rate was increased, until at a dilution rate of $0.71 \mathrm{hr}^{-1}$, the value $(4.4 \%$ of the dry weight) was very

Table 3. Analysis of $\mathrm{PO}_{4}{ }^{3-}$-limited Aerobacter aerogenes NCTC 418 grown at different dilution rates

The analyses were done on samples collected on different days during 'steady state" growth at each dilution rate (D).

\begin{tabular}{|c|c|c|c|c|c|c|}
\hline D & $\begin{array}{c}\text { Bacterial } \\
\text { concentration } \\
\text { (equiv. mg. } \\
\text { dry wt. bacteria/ }\end{array}$ & $\mathbf{K}^{+}$ & $\mathrm{Mg}^{2+}$ & $\underset{\text { driec }}{\mathbf{P}}$ & $\begin{array}{l}\text { RNA } \\
\text { ia) }\end{array}$ & Carbohydrate \\
\hline 0.09 & $6 \cdot 01$ & $0 \cdot 80$ & $0 \cdot 106$ & $0 \cdot 98$ & $5 \cdot 4$ & $18 \cdot 1$ \\
\hline $0 \cdot 09$ & $6 \cdot 14$ & 0.78 & $0 \cdot 099$ & 0.98 & $5 \cdot 0$ & 16.9 \\
\hline $0 \cdot 18$ & $4 \cdot 41$ & $1 \cdot 00$ & $0 \cdot 134$ & $1 \cdot 35$ & $7 \cdot 6$ & $13 \cdot 6$ \\
\hline $0 \cdot 18$ & $4 \cdot 71$ & $0 \cdot 94$ & 0.127 & $1 \cdot 30$ & $7 \cdot 2$ & $12 \cdot 1$ \\
\hline $0 \cdot 36$ & $3 \cdot 32$ & $1 \cdot 12$ & $0 \cdot 157$ & $1 \cdot 74$ & $10 \cdot 8$ & $8 \cdot 1$ \\
\hline $0 \cdot 36$ & $3 \cdot 00$ & $1 \cdot 23$ & $0 \cdot 193$ & $2 \cdot 02$ & $13 \cdot 4$ & 8.0 \\
\hline $0 \cdot 36$ & $3 \cdot 15$ & $1 \cdot 27$ & $0 \cdot 170$ & $1 \cdot 87$ & $13 \cdot 2$ & $7 \cdot 6$ \\
\hline $0 \cdot 71$ & $2 \cdot 05$ & $1 \cdot 90$ & $0 \cdot 307$ & $2 \cdot 77$ & $18 \cdot 9$ & $4: 4$ \\
\hline 0.71 & $2 \cdot 05$ & $1 \cdot 80$ & 0.307 & $3 \cdot 01$ & $19 \cdot 8$ & $4 \cdot 4$ \\
\hline
\end{tabular}




$$
K, M g, P \text { and } R N A \text { in } A \text {. aerogenes }
$$

like that found for $\mathrm{K}^{+}$-limited $\left(4.7 \%\right.$ at $\left.0.8 \mathrm{hr}^{-1}\right)$ and $\mathrm{Mg}^{2+-l i m i t e d}$ organisms $\left(4.29 \%\right.$ at $\left.0.8 \mathrm{hr}^{-1}\right)$. The carbohydrate of $\mathrm{PO}_{4}{ }^{3-}$-limited Aerobacter aerogenes thus constituted a varying proportion of the bacterial dry weight as a function of growth rate, and the nature of the variation was such that it accentuated any increase in another cellular component with increasing growth rate. Therefore, the relatively great increases in the other four measured components in $\mathrm{PO}_{4}{ }^{3-}$-limited organisms compared with corresponding increases under conditions of $\mathbf{M g}^{2+-}$ and $\mathrm{K}^{+}$-limitation can be partially explained on these grounds.

The $\mathbf{P} / \mathrm{Mg}^{2+}$ molar ratio did not vary significantly with growth rate (Fig. 5); the values reflected the high degree of correlation between the progressive increases in these two components as a function of dilution rate. The average value of these ratios $(\mathbf{7 \cdot 8 7})$ is close to the anticipated value of 8 . Since cellular potassium increased somewhat less, and RNA rather more, than magnesium and phosphorus, molar ratios involving either RNA or potassium, and especially $\mathrm{RNA} / \mathrm{K}^{+}$, varied with growth rate (Fig. 6). However, examination of Figs. 5 and 6 indicates that the variation was essentially confined to dilution rates up to the value of $0 \cdot 36 \mathrm{hr}^{-\mathbf{1}}$. The molar ratios at $0.36 \mathrm{hr}^{-1}$ were similar to those at the highest dilution rate used $\left(0.71 \mathrm{hr}^{-1}\right)$. This is particularly true for the $\mathbf{P} / \mathbf{K}^{+}, \mathbf{R N A} / \mathbf{P}$ and $\mathbf{R N A} / \mathrm{K}^{+}$molar ratios. When the molar ratios obtained at the two higher growth rates are averaged and expressed as a $\mathbf{M g}^{2+}: \mathbf{K}^{+}: \mathbf{R N A}$ (nucleotide): $\mathbf{P}$ ratio, the values obtained $(1: 4 \cdot 09: 4 \cdot 89: 8 \cdot 02)$ are remarkably close to the predicted $1: 4: 5: 8$ ratio.

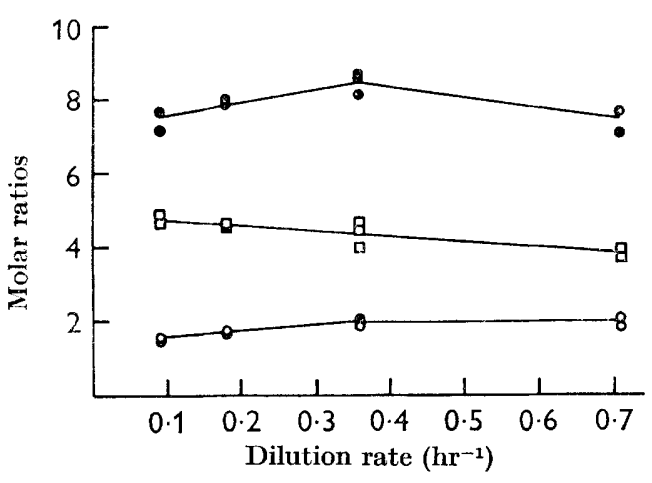

Fig. 5

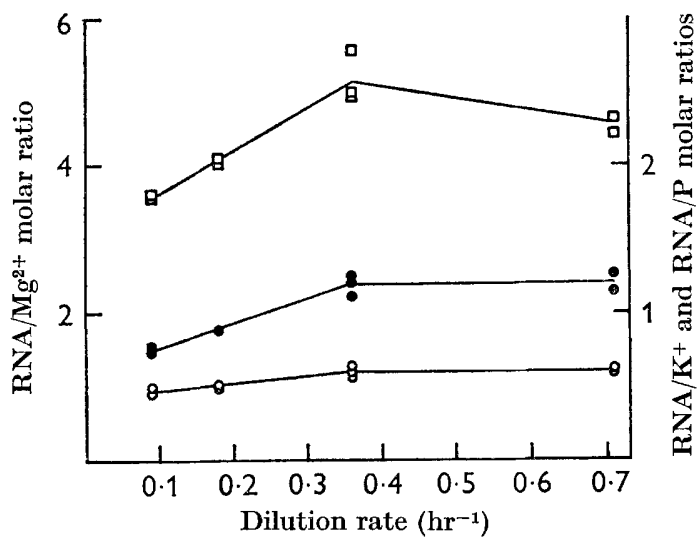

Fig. 6

Fig. 5. Stoichiometry between bacterial potassium, magnesium and phosphorus in $\mathrm{PO}_{4}{ }^{3-}$-limited chemostat cultures of Aerobacter aerogenes NCTC 418, grown at different dilution rates. Molar ratios: $\bullet$, phosphorus:magnesium; $\square$, potassium:magnesium; $O$, phosphorus; potassium.

Fig. 6. Stoichiometry between bacterial RNA and potassium, magnesium and phosphorus in $\mathrm{PO}_{4}{ }^{3-}$-limited chemostat cultures of Aerobacter aerogenes NCTC 418, grown at different dilution rates. For the purpose of calculating molar ratios, an average molecular weight for RNA-nucleotide of 340 was assumed. Molar ratios : $\square$, RNA (nucleotide): magnesium;

, RNA (nucleotide): potassium; O, RNA (nucleotide): phosphorus. 


\section{DISCUSSION}

The aim of the work described here was to measure the variation in potassium, magnesium and phosphorus contents of Aerobacter aerogenes NCTC 418 as a function of its RNA content. Two approaches were used. It is well established that the RNA content of micro-organisms increases with increase in growth rate (Herbert, 1961) and varying the growth rate under two separate growth limitations has been one of the techniques adopted to vary the bacterial RNA content. The second method is dependent on the observation of Tempest \& Hunter (1965) that the RNA content of $\boldsymbol{A}$. aerogenes, growing in a chemostat, varied with temperature at a fixed growth rate. Therefore, in a chemostat, the effect of temperature can be assessed independently of growth rate, which is controlled by a chosen dilution rate. Since the increase in cellular RNA observed by Tempest \& Hunter (1965) as temperature was decreased at a fixed dilution rate, was ribosomal in origin, their results were interpreted in terms of a requirement for an increased number of ribosomes/cell to maintain the rate of protein synthesis imposed by the dilution rate under conditions where the activity of individual ribosomes was decreased by decreasing the temperature. This interpretation is consistent with the suggestion of Ecker \& Schaechter (1963) that the rate of protein synthesis/ribosome particle is constant and independent of growth rate at any one temperature.

The high degree of correlation between the increase in RNA (presumably ribosomal), phosphorus and potassium contents of Aerobacter aerogenes as the temperature was decreased (Table 1 ) is considered to be evidence of an association between potassium and the ribosomal complement of these organisms. The observation that the quantitative relationship between RNA and magnesium is somewhat variable may be an indication that a significant proportion of the cellular magnesium is not bound to the ribosomes under $\mathrm{K}^{+}$-limiting conditions at the low growth rate used. This suggestion might also explain the observation that the plot of $\mathrm{RNA} / \mathbf{M g}^{2+}$ molar ratio against dilution rate, described in a previous paper (Tempest et al. 1966, their fig. 5) exhibited a small positive slope, which can be interpreted as an indication that at higher growth rates, where the ribosome content of the organisms was increased, a larger proportion of the cellular magnesium was associated with the ribosomes.

The participation of phosphorylated intermediates in polysaccharide synthesis and the requirement of magnesium as a co-factor in many enzyme-catalysed phosphate transfer reactions are well established. The varying carbohydrate content of $\mathrm{PO}_{4}{ }^{3-}$-limited organisms may, therefore, not only account for the greater variation of magnesium and phosphorus contents of these organisms with growth rate relative to that found in $\mathrm{K}^{+}$-limited and $\mathrm{Mg}^{2+}$-limited organisms, but might explain also the low $\mathrm{RNA} / \mathrm{Mg}^{2+}$ and $\mathrm{RNA} / \mathrm{P}$ ratios at low growth rates (Fig. 6) on the basis that the synthetic reactions leading to polysaccharide demand significant amounts of magnesium and phosphate. Similarly, the participation of potassium in polysaccharide synthesis (Pulver \& Verzar, 1940; Duguid \& Wilkinson, 1954) may account for the low $\mathrm{RNA} / \mathrm{K}^{+}$molar ratio at low growth rates. The observation that even the $\mathrm{K}^{+} / \mathrm{Mg}^{+}$and $\mathbf{P} / \mathrm{K}^{+}$ratios at dilution rates of $\mathbf{0} .09$ and $0 \cdot 18 \mathrm{hr}^{-1}$ were respectively higher and lower than predicted by the $1: 4: 8$ stoichiometry between magnesium, potassium and phosphorus, suggests that the proportion of cellular potassium 
associated with polysaccharide at low growth rates was relatively higher than the proportions of magnesium and phosphorus likewise involved. On this question, it is interesting to note that Poppen, Green \& Wrenn (1953) found, by histochemical techniques, a correlation between the intracellular distribution of potassium and glycogen in heart and liver tissue.

The results presented in the present paper support the conclusions drawn previously (Tempest et al. 1966) that the major role of potassium in Aerobacter aerogenes (a role which demands the high intracellular concentration of this ion) is to be found in its association with the ribosomes. In the one case where a highly significant difference between the observed stoichiometry and that predicted was shown to occur, an explanation was put forward to account for the deviation. Thus, the relative excess of potassium over the other components of the relationship under $\mathrm{PO}_{4}{ }^{3-}$-limiting conditions at low dilution rates appears to be related to the accumulation of polysaccharide.

The possibility that potassium may be associated with some structural cellular component has, in the past, suffered from lack of convincing evidence in its favour, but recently this ion has been implicated in protein synthesis (Ennis \& Lubin, 1961, 1965; Lubin, 1963). Lubin's conclusion that high concentrations of potassium are necessary for a 'priming reaction' which involves aminoacyl-S-RNA, messenger RNA, ribosomes and optimal concentrations of magnesium to yield an active complex for polypeptide synthesis is strengthened by evidence of Nakamoto et al. (1963) for the existence of such a complex. In cell-free systems, $\mathrm{NH}_{4}{ }^{+}$appears to be two to three times more effective than $\mathrm{K}^{+}$, but examination of the intracellular concentration of $\mathrm{NH}_{4}{ }^{+}$favours the in vivo participation of $\mathrm{K}^{+}$(Lubin \& Ennis, 1964). Another observation which appears to emphasize the specificity of potassium in protein synthesis was made by Lubin (1964), who pointed out that mature erythrocytes of some mammals contain low intracellular concentrations of potassium, but are rich in sodium; they do not synthesize protein.

Since at least three inorganic ions $\left(\mathrm{K}^{+}, \mathrm{Mg}^{2+}, \mathrm{PO}_{4}{ }^{3-}\right)$ appear to be required in significant quantities for the synthesis and proper functioning of the proteinsynthesizing apparatus of the cell, it is interesting to note that a close association between ion accumulation and growth in plants has been observed. Potassium, in particular, is located in regions of rapid growth, namely the apices and young leaves (Steele, 1949). Cation uptake associated with active growth (as distinct from vacuolar accumulation which also occurs in non-growing storage tissues) has been accounted for in terms of the neutralization of negative charges present on nondiffusible anions, which are synthesized during growth (Briggs, Hope \& Robertson, 1961). Inasmuch as the nucleic acids of the ribosomes may account for a large proportion of such polyanions in the rapidly dividing cells of meristematic tissue, this explanation is consistent with the present proposition. Furthermore, Wood \& Braun (1965) have shown that the rapidly growing cells of crown gall tumour tissue differ from cells of normal tissue in possessing more efficient mechanisms for uptake of potassium and phosphate, and higher concentrations of these cellular components. These authors believe that the transition from a normal to a fully autonomous tumour cell is dependent upon the development of an enhanced ability to absorb inorganic ions, higher intracellular concentrations of which result in the activation and loss of regulation of several growth-limiting synthetic processes. 
The authors are indebted to Dr D. C. Ellwood, Dr D. Herbert and Mr R. E. Strange for their discussion and criticism of the work. We gratefully acknowledge the skilled technical assistance of Mr T. Dunham.

\section{REFERENCES}

Blond, D. M. \& Whittam, R. (1965). Effects of sodium and potassium ions on oxidative phosphorylation in relation to respiratory control by a cell-membrane adenosine triphosphatase. Biochem. J. 97, 523.

Briggs, G. E., Hope, A. B. \& Robertson, R. N. (1961). Electrolytes and Plant Cells. Botanical Monographs. Ed. by W. O. James, vol. 1. Oxford: Blackwell Scientific Publications Ltd.

Dicks, J. W. \& Tempest, D. W. (1966). Potassium metabolism in Aerobacter aerogenes. Biochem. J. 99, $7 \mathrm{P}$.

Dixon, M. \& WEBb, E. C. (1964). Enzymes. Second edition. London: Longmans Green and Co. Ltd.

Duguid, J. P. \& Wilkinson, J. F. (1954). Note on the influence of potassium deficiency upon production of polysaccharide by Aerobacter aerogenes. J. gen. Microbiol. 11, 71 .

Ecker, R. E. \& Schazchter, M. (1963). Ribosome content and the rate of growth of Salmonella typhimurium. Biochim. biophys. Acta 76, 275.

Eody, A. A. \& Hinshelwoon, C. N. (1951). Alkali-metal ions in the metabolism of Bact. lactis aerogenes. III. General discussion of their role and mode of action. Proc. roy. Soc. B $138,237$.

EnNis, H. L. \& Lubin, M. (1961). Dissociation of ribonucleic acid and protein synthesis in bacteria deprived of potassium. Biochim. biophys. Acta 50, 399.

Ennis, H. L. \& Lubin, M. (1965). Pre-ribosomal particles formed in potassium depleted cells. Studies on degradation and stabilisation. Biochim. biophys. Acta 95, 605.

Gardner, R. J. (1946). Colorimetric determination of magnesium in plasma or serum by means of Titan Yellow. Biochem. J. 40, 828.

Herbert, D. (1961). The chemical composition of micro-organisms as a function of their environment. Symp. Soc. gen. Microbiol. 11, 391.

Herbert, D., Phipps, P. J. \& Tempest, D. W. (1965). The chemostat: design and instrumentation. Lab. Practice 14, 1150.

KING, E. J. (1951). Micro-analysis in Medical Biochemistry. Second edition. London: Churchill Ltd.

Krebs, H. A., Whittam, R. \& Hems, R. (1957). Potassium uptake by Alcaligenes faecalis. Biochem. J. 66, 53.

LARDY, H. (1951). The influence of inorganic ions on phosphorylation reactions. In Phosphorus Metabolism. Ed. by W. D. McElroy and B. Glass. Vol. I, p. 477. Baltimore: The Johns Hopkins Press.

LeSTer, G. (1958). Requirement for potassium by bacteria. J. Bact. 75, 426.

LUBIN, M. (1963). A priming reaction in protein synthesis. Biochim. biophys. Acta 72, 345.

Lubin, M. (1964). Cell potassium and the regulation of protein synthesis. In The Cellular Functions of Membrane Transport, p. 193. New Jersey: Prentice-Hall Inc.

Lubin, M. \& ENNIS, H. L. (1964). On the role of intracellular potassium in protein synthesis. Biochim. biophys. Acta 80, 614.

Nakamoto, T., Confay, T. W., Allende, J. E., Spyrides, G. J. \& Lipmann, F. (1963). Formation of peptide bonds. I. Peptide formation from aminoacyl-S-RNA. Cold Spring Harb. Symp. quant. Biol. 28, 227.

Partridge, S. M. (1949). Aniline hydrogen phthalate as a spraying reagent for chromatography of sugars. Nature, Lond. 164, 443.

Perry, J. J. \& Evans, J. B. (1961). Role of potassium in the oxidative metabolism of Micrococcus sodonensis. J. Bact. 82, 551.

Poppen, K. J., Green, D. M. \& Wrenn, H. T. (1953). The histochemical localization of potassium and glycogen. J. Histochem. Cytochem. 1, 160. 
Postgate, J. R., Crumpton, J. E. \& Hunter, J. R. (1961). The measurement of bacterial viabilities by slide culture. J. gen. Microbiol. 34, 459.

Pulver, R. \& Verzar, F. (1940). Connexion between carbohydrate and potassium metabolism in the yeast cell. Nature, Lond. 145, 823.

Roberts, R. B., Roberts, Z. \& Cowie, D. B.(1949). Potassium metabolism in Escherichia coli. 2. Metabolism in presence of carbohydrates and their derivatives. J. cell. comp. Physiol. 34, 259.

Rouf, M. A. (1964). Spectrochemical analysis of inorganic elements in bacteria. J. Bact. 88,1545 .

Steele, C. C. (1949). An Introduction to Plant Biochemistry, p. 302. London: G. Bell and Sons Ltd.

Steinbach, H. B. (1962). The prevalence of K. Perspectives Biol. Med. 5, 338.

Strange, R. E., Dark, F. A. \& Ness, A. G. (1961). The survival of stationary phase Aerobacter aerogenes stored in aqueous suspension. J. gen. Microbiol. 25, 61.

Tempest, D. W. \& Hunter, J. R. (1965). The influence of temperature and $\mathrm{pH}$ value on the macromolecular composition of magnesium-limited and glycerol-limited Aerobacter aerogenes growing in a chemostat. J. gen. Microbiol. 41, 267.

Tempest, D. W. \& Strange, R. E. (1966). Variation in content and distribution of magnesium, and its influence on survival, in Aerobacter aerogenes grown in a chemostat. J. gen. Microbiol. 44, 273.

Tempest, D. W., Dicks, J. W. \& Hunter, J. R. (1966). The interrelationship between potassium, magnesium and phosphorus in potassium-limited chemostat cultures of Aerobacter aerogenes. J. gen. Microbiol. 45, 135.

Tempest, D. W., Hunter, J. R. \& Sykes, J. (1965). Magnesium-limited growth of Aerobacter aerogenes in a chemostat. J. gen. Microbiol. 39, 355.

Trevelyan, W. E., Proctor, D. P. \& Harrison, J. S. (1950). Detection of sugar on paper chromatograms. Nature, Lond. 166, 444.

Wood, H, N. \& Braun, A. C. (1965). Studies on the net uptake of solutes by normal and crown gall tumor cells. Proc. natn. Acad. Sci. U.S.A. 54, 1532. 